\title{
ナヴァランガから見たインド・ホイサラ寺院の平面分析 \\ A STUDY OF THE PLANS OF THE HOYSALA TEMPLES THROUGH THE COMPOSITION OF NAVARANGA
}

\author{
矢口直道* \\ Naomichi YAGUCHI
}

\begin{abstract}
This study aims to clarify the characteristics of the plans of the Hoysala temples in south India, in terms of shapes, walls and arrangement of niches of spatial units through the composition of navaranga. The Hoysala temple is composed of several spatial units such as garbhagrha, sukanasi, navaranga, portico, mahamandapa. Though the spatial units have square, rectangular and cross plans, the temple plans are based on almost same size squares, i.e., garbhagrha, sukanasi, the central ankana of the navaranga. It is pointed out that the difference of plan types is based on the difference of the shape and walls of the navaranga.
\end{abstract}

Keywords ; Indian Architecture, Hoysalas, Plan Types, navaranga, ankana インド建築, ホイサラ朝, 平面類型, ナヴァランガ, アンカナ

\section{1.はじめに}

本稿は，南インド・カルナータカ州南部に11世紀から14世紀にか けて栄えたホイサラ朝の時代に建立された寺院（以下，ホイサラ寺 院）の本殿を構成する室の平面形，及びそれぞれの構造に着目した 壁面構成，ニッチの配置を検討した上で，後述のナヴァランガを中 心に室相互の関漸を考察し, さらに平面形, 壁面構成と既報の寺院 本殿の平目類型との相関を考察するものである

既報では，ホイサラ寺院本殿は，それぞれ屝で仕切られたガルバ グリハ (祠堂)，シュカナースィ (前室)，ナヴァランガ (拝殿)， ポルティコ，マハーマンダパ (前殿) の組合せにより寺院本殿が構 成されることを示した。ホイサラ寺院は，まぐさ式構造で垂直方向 の変化が少なく，平面から空間を認識することか溶易である。その 平面類型は, ポルティコ, ナヴァランガ, シュカナースィ, ガルバ グリハが，軸線に沿って一列に配置される一軸型平面（図 1)，一 軸型平面または後述の二軸型平面が並置された平面（図 2），一軸 型平面に加えナヴァランガ両側にガルバグリハ，シュカナースィ等 か左右対称に配置され，全体として軸線か淔交する二軸型平面（図 3）, さらにナヴァジンガのまわりにその他の室が渄刘称に配置さ れる非対称型平面（図4）に分けて論じた。本稿では，まずナヴァ ランガの平面形，構造に着目した壁面の構成，ニッチの配置を概観
した上で，その他の室についても同様に検討し，それら相互の関連 と, 寺院の平面類型と平面形，壁面構成との相関について論じる。 対象は表 I に挙げた 189基の寺院で，マイソール考古局年次報告 書（以下，MAR）に平面図力揭載されているもの，またはそれに準 じて寺院の平面の形状が記述されているものである ${ }^{i ! 2}$ 。フォエケマ がナヴァランガ, マハーマンダパの平面形を分類しているが!:，木 イサラ寺院の室について平面形に着目した研究はほとんどなされて いない。

\section{2. ナヴァランガの構成}

\section{2-1）. ナヴァランガの平面形}

ナヴァランガは, 中央部の四本柱にかかる梁で, アンカナと呼ば れる区画に分割されている。アンカナは柱，ピラスターの内法寸法 をとった区画の名称で，その平面形は正方形または矩形である゙注。 ホイサラ寺院では, 正方形平面のナヴァランガが最も多いため （169基／表II），まずこの平面形について考察する ${ }^{\text {i: 。 }}$

正方形平面のナヴァランガでは，アンカナの幅が中央部とその周 囲で異なることに着目すると，中央部と周囲で，柱間か等しくなる もの（図 1，図 $5 \mathrm{~A}$ ），中央部の柱間が周囲より広いもの（図4， 図13，図5B，C）に分けられる。柱間か等間隔のナヴァランガは 


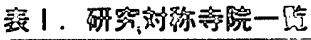

\begin{tabular}{|c|c|c|c|c|c|c|c|c|}
\hline & Gefes & 509 & 幽 & 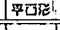 & & 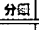 & & \\
\hline & $79 y-n$ & HフルYマT & MAR 1942 Qp. $40-41$. & $\mathrm{AO}$ & 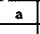 & & -1 & 96 \\
\hline$-\frac{2}{3}$ & $\frac{7 y-\mu-\mu}{7-t-r-v-}$ & 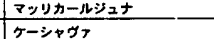 & MAR 1942 0.41. & Ao & a & & $=$ & -97 \\
\hline$\frac{3}{4}$ & 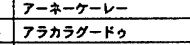 & 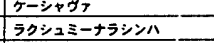 & \begin{tabular}{|l} 
MAR 1939 pp. $74-76$. pl. xxIII. \\
MAR 1936 pp. 12-13. \\
\end{tabular} & $\frac{A 0}{A 0}$ & $\therefore$ & & $=$ & $\frac{98}{99}$ \\
\hline 5 & r-5ン* & \#+1t & MAR 1941 DD. $100-102$. & & $a$ & & $=$ & 100 \\
\hline & 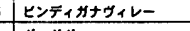 & 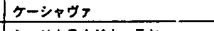 & AR 1939 p. 50. & A0 & a & & $=$ & 101 \\
\hline$\frac{7}{8}$ & 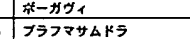 & 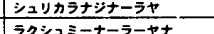 & AR 1940 op. 43-44, Dls. XVI. & AO & a & & $=$ & \begin{tabular}{|c|}
102 \\
103
\end{tabular} \\
\hline 9 & 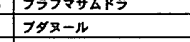 & 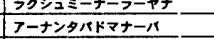 & 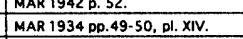 & $\frac{\mathrm{AO}}{\mathrm{AO}}$ & $\begin{array}{ll}a \\
\mathrm{a}\end{array}$ & & - & 104 \\
\hline 10 & |チャンナラーヤハトー & $f_{X}$ & MAR 1939 pp. $78-79$. & AO & $\mathrm{a}$ & & - & 105 \\
\hline 11 & 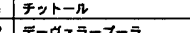 & 1ーシ2ク75 & MAR 1928 p.4, pl.V. & AO & a & & - & 106 \\
\hline$\frac{12}{13}$ & 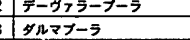 & 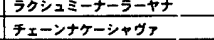 & MAR 1940 pD.45-47. & AO & a & & - & 107 \\
\hline 14 & & $\tau-2<+\gamma$ & \begin{tabular}{|l} 
MAR 1930 p. 5.5 \\
\end{tabular} & AO & 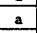 & & $=$ & $\frac{\mid 108}{109}$ \\
\hline & 1953 & |5\%\% & MAR 1917 p.9. & AO & $a$ & & - & 1110 \\
\hline 16 & $\mid \wedge L-K-K$ & 751+-9 & MAR 1930 D. 58. & $\mathrm{AO}_{\mathrm{O}}$ & A & & $=$ & 111 \\
\hline & $A v-\varepsilon-k$ & シャーンティーータ & 58-59. & $\mathrm{AO}_{\mathrm{O}}$ & $\mathrm{a}$ & & $=$ & 112 \\
\hline 18 & $\mid$ ヘーンダー & $\mu-\mu \div 2 y_{\gamma}+-g$ & 6, pl. Vul. & $A_{0} 0$ & 2 & $E$ & & 113 \\
\hline 19 & 105 & 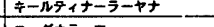 & & Ao & $a$ & & 二- & 114 \\
\hline 20 & 辛 & $2-4+5-2$ & 21-23. & $A^{A 0}$ & $a$ & $k$ & -1 & 115 \\
\hline 21 & 索ーンナンナラ & 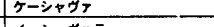 & 30-35. & $\mathrm{AO}_{\mathrm{N}}$ & 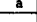 & K & - & 116 \\
\hline 22 & 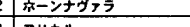 & $1-2,2975$ & & $\mathrm{AO}^{\mathrm{O}}$ & a & & $=$ & 117 \\
\hline 23 & Pon & マソレーシュクフラ & & AD & $a_{3}$ & & - & 118 \\
\hline 24 & フルレーケーレ- & 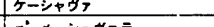 & & $\mathrm{AO}$ & a & & - & 119 \\
\hline 25 & カイタン5 & 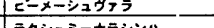 & & AO & a & & - & 120 \\
\hline 268 & 官ーレーサンテー & 50シ2ミ-ナ5シ2M & & $\mathrm{AO}_{\mathrm{N}}$ & & & - & \\
\hline 210 & $4-2, y, y$ & フッララナータ & & A0 & a & & - & 1.22 \\
\hline$\frac{28}{30}$ & 3|マチママラカルタ & マッレーシュタフラ & -41, pl. xVI. & $A_{0}$ & & & $=$ & 123 \\
\hline 29 & 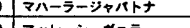 & ラクシスマネーシスダラ & 1.12. & $\mathrm{AO}_{\mathrm{O}}$ & $a$ & & $-i$ & $124\}$ \\
\hline & 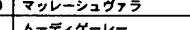 & 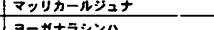 & & A0 & $a$ & & - & 125 \\
\hline & 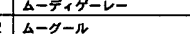 & 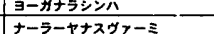 & pl. & AO & $\mathrm{a}$ & & -1 & 126 \\
\hline 33 & 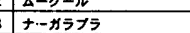 & 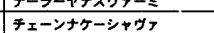 & \begin{tabular}{|l} 
MAR 1 \\
MAR 1
\end{tabular} & $\frac{\mathrm{AO}}{\mathrm{AO}}$ & t & H & $\Rightarrow$ & 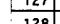 \\
\hline 34 & $7-5$ & $y-x-* 2 y>3$ & d. $x$ vil. & AO & & $n$ & - & 129 \\
\hline 35 & |ラーマナータフう & $5-x-2, y>3$ & 111, pl.V. & A0 & $a-$ & & - & 130 \\
\hline 36 & 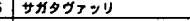 & |ラクシュミーナーラーヤ寸 & MAR 1 & Ao & $\mathrm{a}$ & & $\overline{-}$ & 131 \\
\hline 37 & | -1リyラマ & $\exists-\pi j+5$ & MAR 1 & $\mathrm{AO}_{0} \mathrm{C} \longrightarrow \mathrm{C}$ & $\mathrm{a}$ & & $\because$ & 132 \\
\hline 38 & $\begin{array}{l}\text { |ンーマナータブ } \\
\end{array}$ & 5クシュミーナラシンn & MARI & 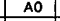 & $\mathrm{a}$ & $E$ & $-i$ & 133 \\
\hline 39 & |シュラタフナイーラコーう & $\kappa-n y_{2} y_{7}+-8$ & 4, pl. v. . & 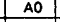 & $\mathrm{a}$ & & - & 134 \\
\hline 40 & |シュランナナメーラコー5 & フルガ & $x x$ & $A_{0} 0$ & $\mathrm{a}$ & & - & 135 \\
\hline 41 & yンyt & 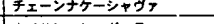 & & $A_{0}$ & $\mathrm{a}$ & $\mathrm{k}$ & -1 & 136 \\
\hline 42 & 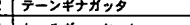 & 亦イサレーシュクフう & 30. & $\mathrm{~A}_{0}$ & $\mathrm{a}$ & & - & 137 \\
\hline 43 & Hang-r-v- & Fメーンナーーシャタフ & |MAR I & $\mathrm{AO}^{\mathrm{A}}$ & & $\mathrm{E}$ & $=$ & 138 \\
\hline 44 & 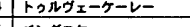 & 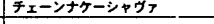 & MAR & $\mathrm{AO}^{\mathrm{A}}$ & & $\mathrm{E}$ & - & .139) \\
\hline 45 & 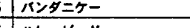 & $\mid<x=1$ & -67. & $\mathrm{AO}_{\mathrm{O}}$ & a & & $=$ & 140 \\
\hline 46 & $\mid \mu \nu-\varepsilon-k$ & 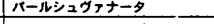 & $.101 \cdot 102$ & $\mathrm{AO}_{\mathrm{AO}}$ & 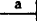 & $\underline{E}$ & -1 & 141 \\
\hline 47 & tレ-カタル-ル & 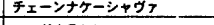 & $\mathrm{m}$ & $A_{0} 0$ & & & - & 142 \\
\hline 48 & シンカーー5 & ヨーカナランンハ & 70-711. & $\mathrm{A}_{0}$ & a & & $=$ & 143 \\
\hline 49 & $\frac{\alpha-\mu-\mu}{20}$ & フンタランー & ar,p. 17 . & $A_{0} 0$ & & $\mathrm{H}$ & - & 144 \\
\hline 50 & 7ンハレー & 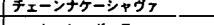 & & $\mathrm{A}_{0}$ & & & $=$ & 145 \\
\hline & 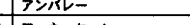 & $\mid 0-\pi-3 / 2, y>5$ & & $\mathrm{~A}^{\mathrm{A}_{0}}$ & & & $=$ & 146 \\
\hline 32 & $7>-\hbar-5-v-$ & 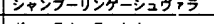 & 7.78 & $\mathrm{AO}_{\mathrm{H}}$ & & & - & 147 \\
\hline 33 & $4+\alpha-\mu-n$ & 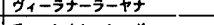 & 15-16, pl.1.1. & $\mathrm{A}_{0} \mathrm{C}$ & & $k$ & $=$ & 148 \\
\hline${ }^{44}$ & 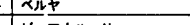 & $\exists x-y+x-2 y+97$ & & $\mathrm{AO}_{\mathrm{A}}$ & & & $-{ }^{-}$ & 149 \\
\hline 58 & 七ーママナハッリ & y- & & $\mathrm{AO}^{\mathrm{A}}$ & a & $\underline{E}$ & - & 150 \\
\hline 58 & Fryt & $8=257$ & & A0 & & & - & $151]$ \\
\hline 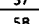 & 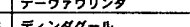 & \begin{tabular}{|l|l|}
$5-x$ \\
$7-4 x$
\end{tabular} & & A0 & & & - & 152! \\
\hline 50 & 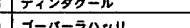 & & & A0 & 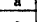 & & - & 153] \\
\hline$\frac{30}{60}$ & $\frac{1}{17-x-7 n=1}$ & & & A0 & -4 & & & 154 \\
\hline$\frac{0}{61}$ & 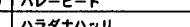 & 91 & & 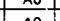 & 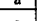 & $k$ & 二 & 135 \\
\hline$\frac{11}{62}$ & 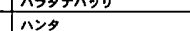 & 22973 & & $\begin{array}{cc}A_{0} \\
A 0\end{array}$ & 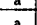 & & $=$ & 156 \\
\hline$\frac{06}{63}$ & 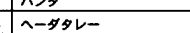 & 促- & & Ant & & & $=$ & 158 \\
\hline 64 & 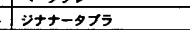 & $=-\infty$ & $\mid \mathbf{x}$. & AD & $a$ & $k$ & - & 159 \\
\hline 65 & 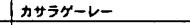 & |カขレーシ29フラ & & AO & & $E$ & $=$ & 160 \\
\hline 66 & $\mid \gamma-レ-\forall y テ-$ & $5 / 1 \times 5$ & & AO & $\mathrm{a}$ & & - & 161 \\
\hline 67 & $\mid r-\nu-\psi$ & 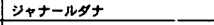 & & A0 $>0$ & & & - & 162 \\
\hline 68 & $\mid=-5-\pi$ & 975 & pl. xil. & ${ }_{A 0}$ & $\therefore$ & & - & 163 ! $>$ \\
\hline 69 & 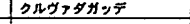 & r & & $A_{0}$ & $\therefore$ & & $=$ & 164 \\
\hline 70 & $\mid a-\neq \%$ & $\begin{array}{llll} & 0\end{array}$ & & ${ }_{A 0}$ & $a$ & & - & 165 \\
\hline 71 & $\nabla$ マントー & & & $\mathrm{AO}^{\mathrm{A}}$ & $\mathrm{a}$ & & -1 & 166 \\
\hline 72 & ママンレー & & & $\mathrm{AO}^{\mathrm{A}}$ & & & - & 167 \\
\hline 73 & 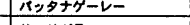 & 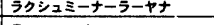 & & $\mathrm{AO}^{\mathrm{AO}}$ & & & - & t| \\
\hline 74 & 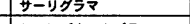 & & & ${ }_{A 0} \mathrm{O}$ & 2 & & - & 169 \\
\hline 75 & $4= \pm+27$ & -9 & & AO & a & & - & 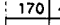 \\
\hline 76 & $\mid$ & 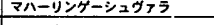 & & 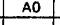 & $\mathrm{a}$ & & - & $f$ \\
\hline 77 & $4=250$ & & EC & 0 & $a$ & & - & \\
\hline 78 & 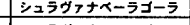 & $t-5 t$ & & $\mathrm{AO}^{\mathrm{B}}$ & $\therefore$ & & - & 173 \\
\hline 79 & $4 \pm 25 y$ & & & $\mathrm{AO}^{0}$ & $a$ & & - & 174] \\
\hline 80 & |g:日月 & & & $\mathrm{AO}_{0}$ & $\therefore$ & & $=$ & 5] \\
\hline 81 & 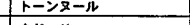 & $-5-5-1$ & & $A^{A 0}$ & $\mathrm{a}$ & $\underline{E}$ & - & 176 \\
\hline 82 & 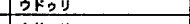 & & & $\mathrm{AO}^{\mathrm{O}}$ & $a$ & & - & 177 \\
\hline 83 & 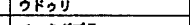 & & & $\mathrm{A}_{0}$ & & & - & 8 \\
\hline$\frac{84}{85}$ & $x-9, y=1$ & & & $\mathrm{AO}_{0}$ & a & & $=$ & 邹 \\
\hline 83 & 3 & & & $\mathrm{AO}_{0}$ & & & $=1$ & 1800 \\
\hline & & & & $A^{A 0}$ & & k & E. & \\
\hline$\frac{6}{8}$ & 33 & & & $\mathrm{AO}^{\mathrm{N}}$ & & & $\exists$ & 1824 \\
\hline 80 & $\frac{7-x-1}{404}$ & & & & $\underline{4}$ & & $E$ & \\
\hline 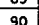 & x & & & $A 0$ & $\Delta$ & $\underline{E}$ & $E$ & 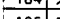 \\
\hline 我 & 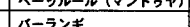 & & & $\mathrm{A}_{0}$ & $a^{2}>>$ & & $=$ & \\
\hline 9. & イリハラーフラ & 㘯 & & $a_{0}$ & $a$ & & $\bar{E}$ & 象 \\
\hline 93 & $x+y=\pi-n$ & & & & & & & . \\
\hline 94 & 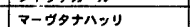 & -1, & tann & 40 & & $\pi$ & & . \\
\hline 95 & $T=-$ - & シ・テーシンタプ & MAR 1947-56 p.34, pl.x & & & & & \\
\hline
\end{tabular}

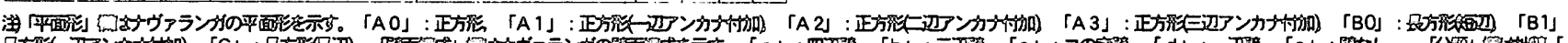
品方形

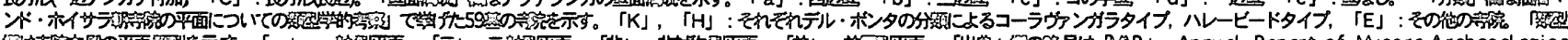

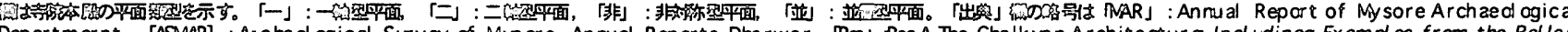

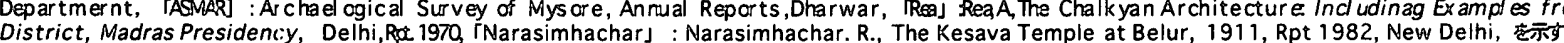




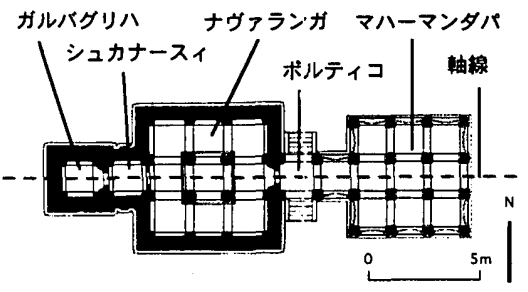

図 1.一型平面 (正方形平面, 四召暨) の例。 チェーンナケーシャヴァ寺院，ヒレーカタルール 平面図。（MAR 1926 pl. II!. をもとに筆者作成。 以下の图も同栐。)

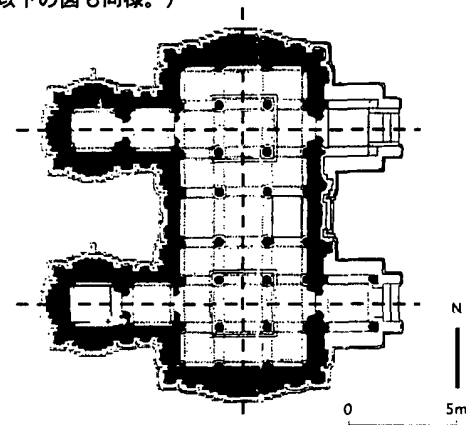

図2. 並置型平面（長方形，四辺壁）の例。 シャンフリンゲーシュヴァラ寺院，スィンダガッタ， 平面图。(MAR 1920 pl. XIV.)

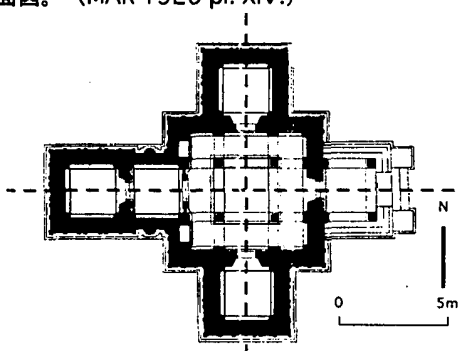

図3. 二鮋型平面（正方形，四辺壁）の例。 ハリハレーシュヴァラ寺院，ハリハラーブラ,

平面图。(MAR 1942 pl. IV-1.)

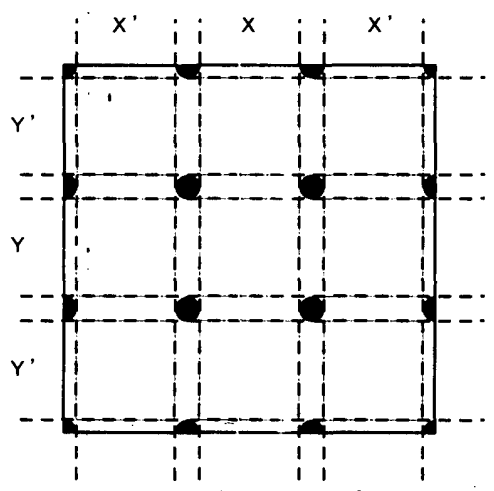

A. 等分割 $\left(X=X^{\prime}\right)$

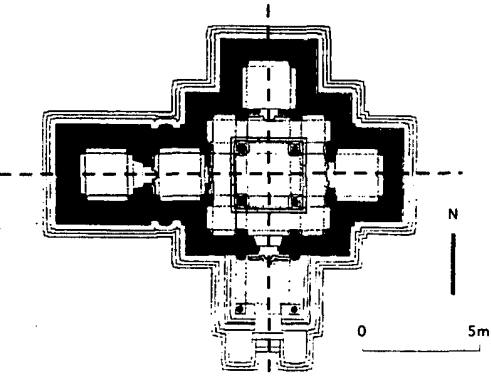

图4. 非対称型平面（正方形，四辺賀）の例。 シャンブリンゲーシュヴァラ寺院，ケーレー サンテー, 平面図。(MAR 1945 pl. XIII.)

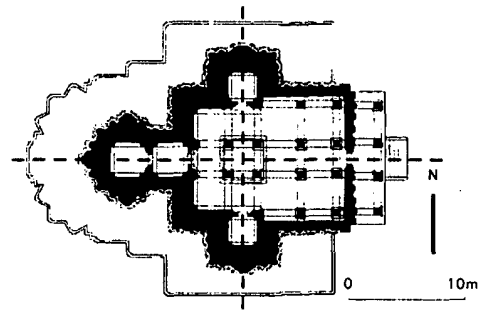

図6.二挿型平面（長方形，四辺壁）の例。 サウムヤケーシャヴァ寺院, ナーガマンガラ, 平面图。(MAR $1925 \mathrm{pl}$. IV.)

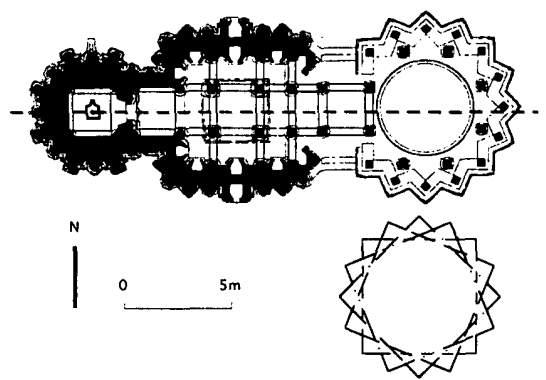

图7.一型平面（一辺アンカナ付加，三辺壁），星形 平面のマハーマンタバの例。イーシュヴァラ寺院（E）， アラシーケーレー，平面图（上），マハーマンタパ平面の 棁式图 (下)。(MAR $1930 \mathrm{pl}$. XIV.)

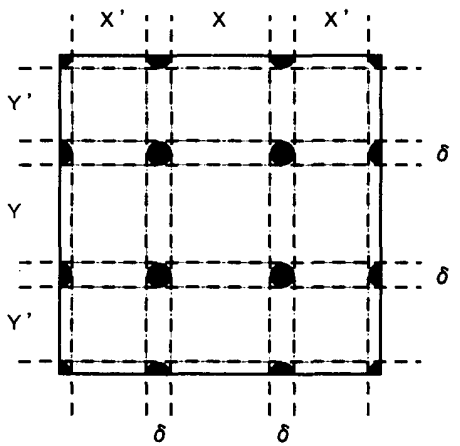

B.不等分割 I $\left(X=X^{\prime}+\delta\right)$

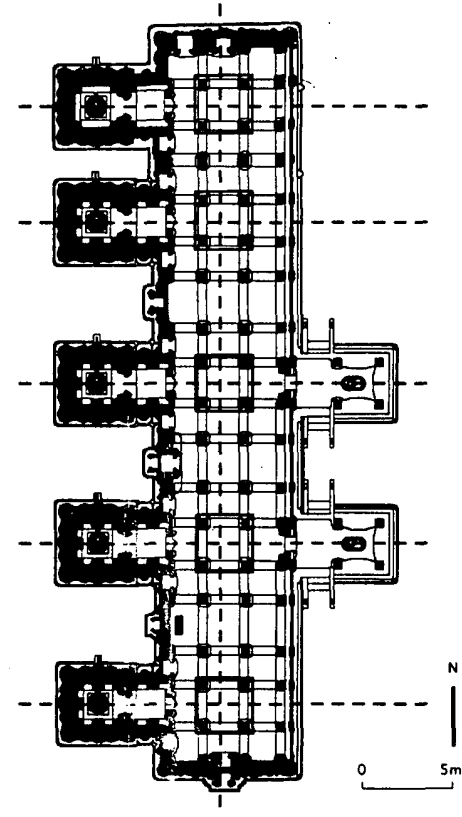

因8、並整犁平面（長方形，三辺暨）の例。 バンチャリンゲーシュヴァラ寺院, コーヴィンタナ ハッリ，平面图。(MAR 1933 pl. IV.)

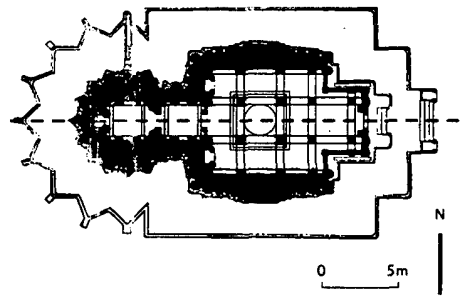

図9. 一轴型习湎（一㲽アンカナ付加，三㳄壁） の例。チェーンナケーシャヴァ寺院，アララ クッペ, 平面图。(MAR $1918 \mathrm{pl}$. VII.)

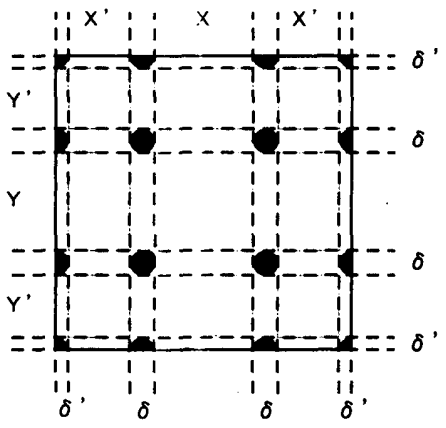

C.不等分割 II $\left(X=X^{\prime}+\delta+\delta^{\prime}\right)$

図5.ナヴァランガの分割

九つのアンカナの大きざがほほ等しく, 全て正方形に分割されてい る。中央部が広い場合をみると，図 5 Bでは，中央アンカナの柱間 寸法 $(\mathrm{X})$ は，柱の中块側からピラスターの内面までの寸法に等し く $\left(\mathrm{X}^{\prime}+o\right)$, 図5Cでは, 柱の中央側からピラスターの中心ま での寸法と等しい（X'+ $+\delta+\delta ')$ 。つまり，それぞれ柱の幅， 柱ととピラスターの幅の分だけ，周囲のアンカナの幅が狭くなって いる。このため, アンカナの大きさは中央アンカナが最も大きい正 方形，四隅のアンカナは柱の太さ分だけ，または柱とピラスターの
太さ分だけ一辺が小さい正方形となる。さらにこの二種類の正方形 の一辺をそれぞれ辺にもつ長方形アンカナがあって, 全体で正方形 平面を構成している。このようにナヴァランガの正方形平面は四本 の柱で仕切られた中央のアンカナを基準として，そのまわりに入れ 子状に周囲のアンカナか酒置されているものと理解することができ る。

このようなナヴァランガの正方形平面の各辺の中央にアン カナが付加的に配置されたものが見られ流，ガルバグリ八に 


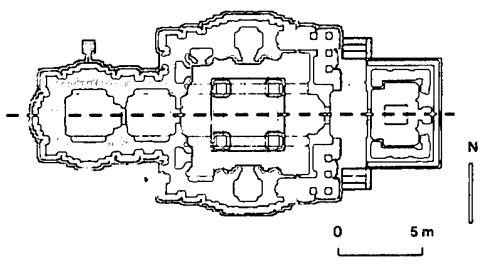

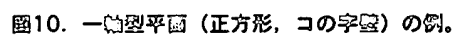
フラフターシュヴァラ紊院，キッケーリ，平圂国。 (MAR 1915 pl. X.)

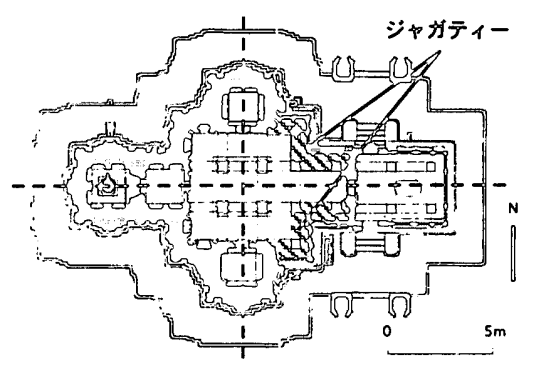

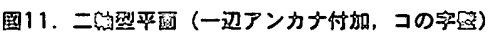
の䟝。マッリカールジュナ院，バスラール，亚面图。

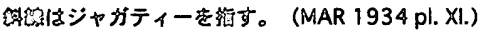

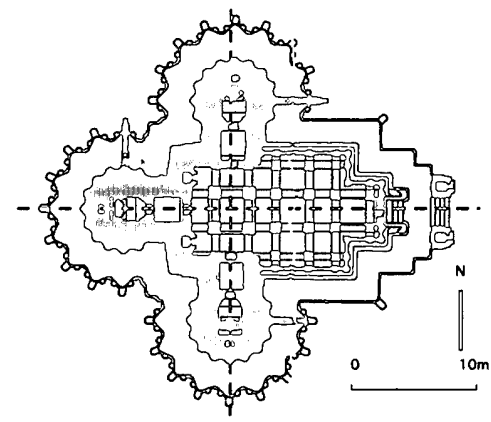

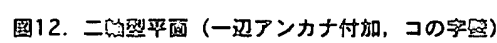
の湖。テェーンケケーシャヴ寺院，ソーマゲータ プラ, 平回国。(MAR 1932. pl. VI.)

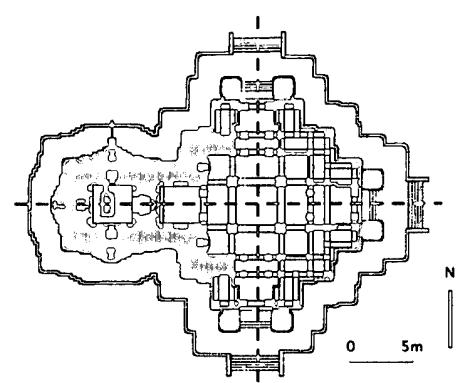

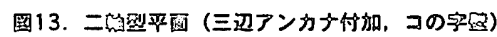
の剖。キールティシーラーやゲ寺院，タラタードゥ， 严国图。(MAR $1932 \mathrm{pl}$. III.)

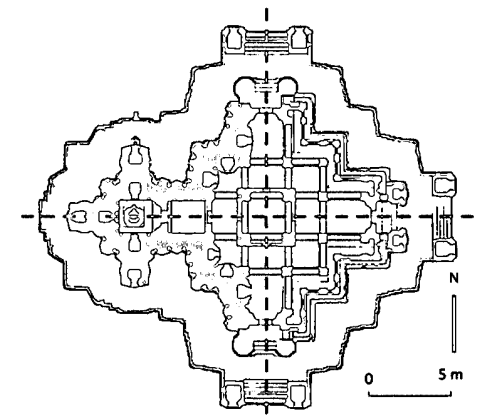

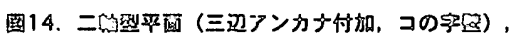
ガルパダリハ内のニッチの則。ソーターーシュヴァラ 寺院，ハールナ゙ハッリ。(MAR 1933 pl. XV.)

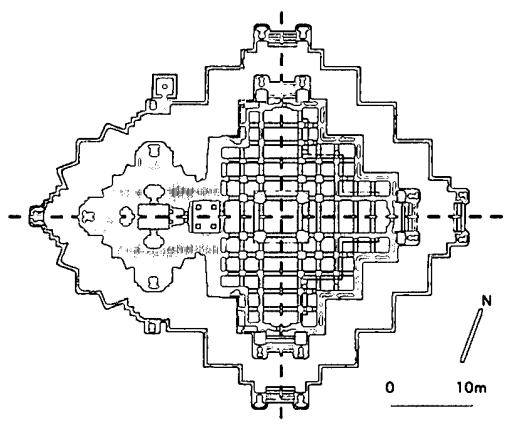

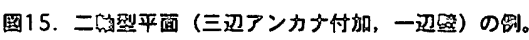
テェーンゲケーシャヴァ告院，ベールール，平面图。

(Narasimhachar, The Kesava temple at Belur, pl. II.)

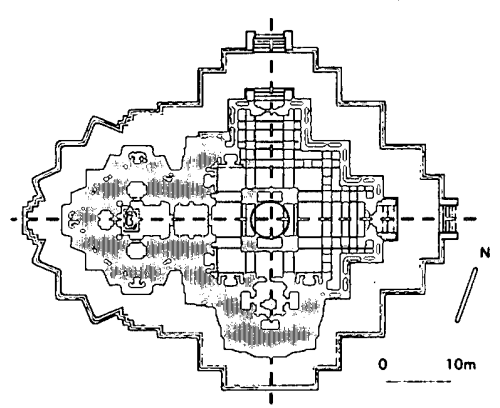

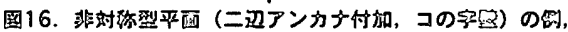
カッペーテェンニダラーヤ察宛, ベールール。 (Narasimhachar, The Kesava temple at Belur, pl. II.)

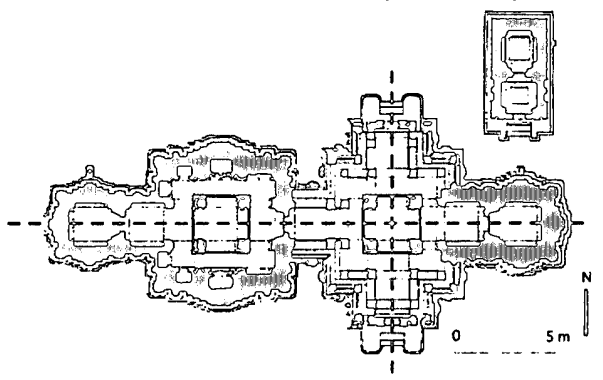

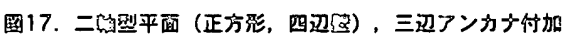

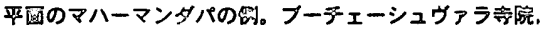
コーラヴンンカラ。(MAR 1933 PI. X.)

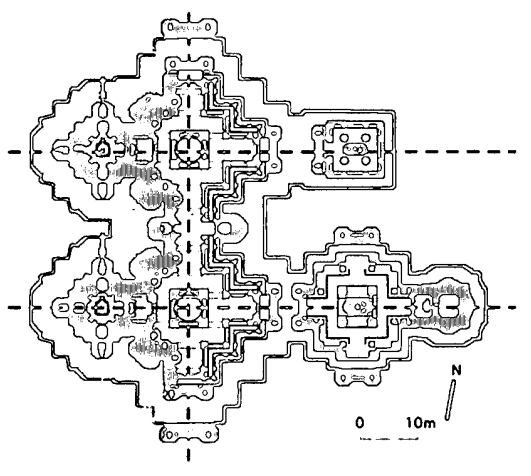

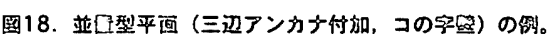

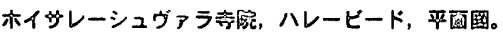
(MAR $1930 \mathrm{pl} . \mathrm{X}$ )
のみ付加的アンカナか眍置されたもの（6基/163，164，165，166， $167 ， 168 ， 169^{\prime 17} /$ 図9，11），これに直交する軸線上に付加的アン カナか酒置されたもの（2基／170，171/図16），三辺に付加的ア ンカナか眍置されたもの（5基/172，173，174，175，176/図13, 14，15）に分けることができる。これらのアンカ十付加平面で，正 方形平面の周りに配置されたアンカナはナヴァランガ中央部のアン カナと同じ大きさである゙

長方形平面のナヴァランガには，その長辺に複数のガルバグリハ， シュカナースイが接するものが 6 基（184，185，186，187，188， 189／図2，8），短辺にガルバグリハ, シュカナースイか接する ものが7基ある（177, 178,179，180１81，182，183/図6，12）。 前者はそれぞれのガルバグリハに対応する正方形平面のナヴァラン ガの間に，ナヴァランガ中央部と同一幅のアンカナか挿入されてひ とつの漸綂したホールか構成されている注。後者をみると, 三つの 付加的アンカナが入側に配置されているものと（図6）, 長方形 平面に中央アンカナと大きさの等しいアンカナが入口部分に配置さ
れているものがある（図12）。

ホイサラ寺院のナヴァランガは，中央部の四本の柱で九分割され た正方形平面を基本としているが，この正方形に中央部のアンカナ と大きさのほ㩐しい付加的アンカナか淍囲い配置されることによっ て他の平面形が派生しているものと考えることができる。

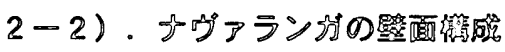

ナヴァランガの壁面ばきい，四辺を壁に囲われたものと (167基)， 一部を腰壁とやや小型の柱で囲われたもの（22基）に分けて考える ことができる (表II）。後者はジャガティーと呼ばれる構造で主11， 腰壁の上に二重に丈が半分の半柱をまわして梁を支え, 外側の柱に はジャーラカと呼ばれる格子空が入る（図11）湆12。格子空は柱の 外側に取付けられ，内側には腰かけか取付けられるが (図12)，例 外的に内側の柱に格子空力取付られるものが見られる（図10）。

四辺か壁に囲われたナヴァランガは正方形，長方形平面にみられ るが，正方形平面が大多数を占める（161基）。長方形平面のナヴァ 
表II. ナヴァランガの平面形と壁面

\begin{tabular}{|c|c|c|c|c|c|c|}
\hline 壁面掅成 & a : 四沐壁 & $\mathrm{b}:$ 三刀骂 & c: コの字留 & d: - 讬照 & e:䧺なし & \\
\hline 平面形 & e & a. & i & & & \\
\hline AO: 正形 & 161 & - & 1 & - & 1 & 163 \\
\hline 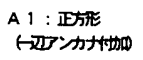 & - & 2 & 4 & - & - & 6 \\
\hline 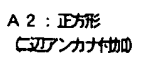 & - & - & 2 & - & - & 2 \\
\hline 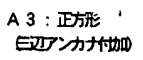 & - & - & 3 & 2 & - & 5 \\
\hline 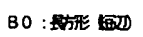 & 5 & - & 1 & - & - & 6 \\
\hline 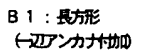 & - & - & 1 & - & - & 1 \\
\hline 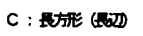 & 1 & 3 & - & 2 & - & 6 \\
\hline 斯 & 167 & 5 & 12 & 4 & 1 & 189 \\
\hline
\end{tabular}

注）表中の模式四の太楾燳面を，点楾恼ジャガティーまたは壁のない部分を示す。表中

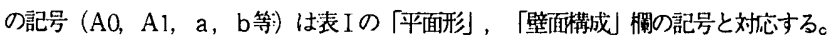

ランガは短辺にガルバグリハ, シュカナースイがつながるものが 5 基（177-181/図6），長辺につながるものが1基である（184/図2）。

三辺か壁に囲われるナヴァランガは（5基/164，165，185，186, 187），一辺アンカナ付加平面と長方形平面にみられる。一辺アン カナ付加平面はジャガティーか㳔加的アンカナと一体の構造のアラ ラグッペのチェーンナケーシャヴァ寺院（図9），ジャガティーの ないアラシーケーレーのイーシュヴァラ寺院 $(\mathrm{E})$ 注13 である (図 7）。ゴーヴィンダナハッリのパンチャリンゲーシュヴァラ寺院の ように横列配置の長方形平面を持つナヴァランガでも，同様に三辺 か壁で囲加れている（3基／185，186，187/図8）。

コの字形に壁に囲われたナヴァランガは (12基)，正方形（1 基 /162/図10），長方形（1基／182），アンカナ付加平面にみられ る。一辺アンカナ付加平面は, 正方形平面の一辺江拊加的アンカナ か酒己置されたものと（166，167，168，169/図11），長方形平面に 配置されたものがあるが（183/図12），いずれもナヴァランガの 入口を除く三辺にガルバグリハが配置されている。二辺アンカナ付 加平面では (170，171/図16)，ナヴァランガを流さんで二組のガ ルバグリハとポルティコが直交配置されている。三辺アンカナ付加 平面をみると，左右入口のガルバグリ八側までは壁で，その反対側 がジャガティーとなるものや $(172 /$ 図14)，左右入口の両側がジャ ガティーになるものがある（173/図13）。ハレービードのホイサ レーシュヴァラ寺院蚔＼cjkend，ハールナハッリのソーメーシュヴァラ寺院

（172）の三辺アンカナ付加平面のナヴァランガが並置されている ものと見ることができる。（174/図18）。

一辺壁のナヴァランガは (4 基)，正方形平面ではみられないが， 長方形平面のナヴァランガの長辺にガルバグリハか泣置するもの (188，189），三西アンカナ付加平面でみられる $(175 ， 176 /$ 図15）。 前者は，複数のガルバグリハとシュカナースィ，ナヴァランガの一 辺がひと文まりであり，後者は，ガルバグリハ, シュカナースィ と，ナヴァランガの一辺の壁面からなるまとまりが，その他の三辺 にはポルティコとナヴァランガの一辺のジャガティーからなるまと
まりか配置されているものと考えることができる（図15）。

ドーッダガッダヴァッリのラクシュミーデーヴィー寺院では

(163），壁のないナヴァランガの周䧃にガルバグリハ，シュカナー スィか配置され，これらと接する部分をのぞいてジャガティーで囲 われる。ナヴァランガのピラスターは中央の四本柱にかかる梁が壁 に接するところに梁を受ける形で設けられるが，このようなナヴァ ランガはこの寺院を除いてはみられない。ジャガティーの腰壁は, ナヴァランガの壁厚と等しく，上述のように四通りの取付け方があ ることから，壁の一部がジャガティーに置き換わったものと考えら れ，少なくとも計画上は亘換性があったものといえよう。

\section{2-3）. ナヴァランガ内のニッチの配置}

神像をまつるナヴァランガのニッチはピラスターの間の壁面に穿 たれ，シカラ風の上部構造を模したレリーフて装飾される涪14。シ カラ風の上部搆造体は数本のピラスターに支えられ，ガルバグリハ の入口同様，開口部脇にはドゥヴァーラパーラ (門神) がまつられ る。ナヴァランガにニッチが設けられている寺院は51基確認できる が, ガルバグリ八のある側の壁にシュカナースィの入口をはさんで 左右対称に二つ設けられているものが最も多い（23基/図 $3 ， 12$, 13）。複数のガルバグリハがまつられる寺院でも仳15.それぞれの ガルバグリハについて二つずつニッチが設けられる涪16（3基／89,

115，182）。さらに主ガルバグリ八の前にあるシュカナースイ両脇 のニッチに加え, 左右側壁のガルバグリ八寄りに設けられる場合が ある（4基/34，166，168，169/図11）。また三辺アンカナ付加 平面のナヴァランガでは, 左右の袖郎にあるニッチを含めて六つ設 けられるものがみられる（2基/図14，17）。これらの寺院をみる とガルバグリハとその䎟脇のニッチが組合わされていると考えるこ とができる。

一方, ジナナータプラのシャーンティナータ寺院では (64)，ナ ヴァランガ俔壁中央に向い合って設けられ，コーラヴァンガラのブー チェーシュヴァラ寺院ではシュカナースイ両脇, ナヴァランガ矅 に二つずつ設けられている（123/図17） ${ }^{i 117 。 ア ラ シ ー ケ ー レ ー ~}$ のイーシュヴァラ寺院（E）ではナヴァランガか壁面で囲われると ころすべてにニッチが設けられている（165/図7）。このように ナヴァランガ側壁中央にニッチが設けられた寺院では (10基)，中 央のニッチがその他に比べて大きく、したがってまつられた神像も 大きいため，従ガルバグリ八に準して機能をしていたことが考えら れる。また並置型平面寺院では, 上述のニッチの位置に加え, 並置

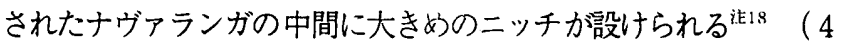
基 /174，186，187，188/図8，18）。

ニッチが非対称に配置されるものをみると（5基），ニッチが一 つの寺院では（3基/70，146，180），シュカナース脇の左右い ずれかに位置する゙非19。キッケーリのブラフメーシュヴァラ寺院で はニッチはガルバグリ八雨脇, ナヴァシンガ偩壁中央に加之, ナヴァ ランガ右側壁のガルバグリ八寄りにあるなど（162/図10)，これ らの寺院でニッチか非㸚称に設けら礼る理由は判明していない。 辺アンカナ付加平面のベールールのカッペーチェーンニガラーヤ寺 院では (170/図16)，コの字形の壁に囲われた一軸型平面と，一 辺か壁に囲われた一軸型平面が十字に配置され，二ッチの配置もそ れぞれのシュカナースィの両脇にあるものが複合しており，寺院平 
面全体では非対称であるが，それぞれのガルバグリハに至る軸線に ついてはテッチの配置を含めて左右対称なのである。

このようにナヴァランガのニッチの配置をガルバグリハの位置と の閔漸でみると，ナヴァランガ各壁の中央部に位置するガルバグリ 八，または大きめのニッチの両側に一対のニッチを配置し，これに 加えて左右側壁のガルバグリハ寄りに一対のニッチを設けており， ガルバグリハを中心としてニッチか酒㯰されている。

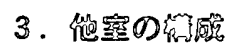

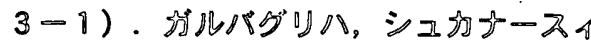

ガルバグリハ, シュカナースィの平面形は, 幾つかの例外をのぞ いて正方形である洁20 。壁面はすべて壁に囲われており，四隅にピ ラスターがあって梁型を受けることが多いが, ナヴァランガのよう に一部をジャガティーで囲われたものはみられない。

ガルバグリハのニッチは12基の寺院で確認でき, 後壁に一つ設け られるものが 4 基（9，139，164，183/図9），入口から向って右 側に一つ設けられるものが1基（100），入口を除く壁面に一つず つ, 合計三つ設けられるものが 7 基（167，168，170，172，173， 174，175/図14) である。ニッチのある寺院ではそれぞれのニッチ の両脇にさらにピラスターか設けられている注21。ニッチのない寺 院の壁面をみると，四隅にピラスターがあって梁型を受けることが 多いが, ニッチがあるものと同じように各壁に二本のピラスターが あるものと，各壁中央にピラスターが一本あるものが見られるが， 両者は構造体とは無関係である。ひとつの寺院に複数のガルバグリ 八があるものは，主ガルバグリハと同じようにピラスター, ニッチ か眍置される場合があるが（図12），主ガルバグリハよりもピラス ターの数が少なくなる湯合もあり 図11），一概には把握できない。

シュカナースイにニッチが設けられることはなく，ピラスターは ガルバグリ八同様，四隅に一本ずつ設けられることが多い。ガルバ グリハとの関軏でピラスターの配置をみると，ガルバグリハの四隅 以外にピラスターがある場合，ガルバグリハと同じようにピラスター か眍置される場合と（図9），シュカナースィのピラスターの数の 方が少ない場合があり (図18)，一貫性は見られない。このように ガルバグリハ, シュカナースィのピラスターは構造体とは関連性の 弱い装飾的なもので，室内壁を分節するものであるといえよう。

\section{3ー2). ポルティコ, マハーマンダハ}

ポルティコの平面形は，三つのアンカナによる長方形平面はナー ガマンガラのサウムヤケーシャヴァ寺院をのぞき（図6)，すべて 正方形平面のアンカナひとつで構成される注22。ポルティコはジャ ガティーによって屋根を支えるが，ポルティコ前面にナンディー堂 またはマハーマンダバが位置する場合には，ジャガティーは設けら れない (図10)。またニッチは設けられない。ナンディー堂は 4 基 の寺院にみられるが $(162,169,174,187)$ ，一つのアンカナにナ ンディを安置する（図10）。

マハーマンダパは1基の寺院にみられるが，その平面形は，正方 形平面（7基 $/ 46,47,49,136,141,157,174)$, 長方形平面 （1 基/175） 注23，アンカナ付加平面（5基/86，122，123，133， 174），星形平面（1基／165）である。正方形平面はアンカナ一つ で構成されているもの除き（141），中央の四本柱とそのまわり
の12本の柱で支えられたもので九分割されたナヴァランガと同じ平 面を呈する（図1）。アンカナ付加平面のマハーマンダパには，九 分割の正方形平面の各辺中央に付加的アンカナがーつ配置された平 面と, 25分割の正方形平面の各辺に一つのアンカナ, または三つの アンカナか酒㯰され，さらに一つのアンカナか置かれる平面がある。 これらのマハーマンダパの平面形は, ナヴァランガ同様に中央のア ンカナと同じ大きさのアンカナが正方形平面のまわりに配置された ものと考えることができる。星形平面のマハーマンダパは アラシー ケーレーのイーシュヴァラ寺院 (E) にのみみられ，正方形を22.5 度ずつ回転させた幾何学図形に基づいている（図7）。

マハーマンダパは, ジャガティーもしくは柱で上部構造を支え， 壁で囲われることはない。ニッチが設けられることもないが，各辺 の中央に祠堂が設けられることがある（図17，18）。コーラヴァン ガラのブーチェーシュヴァラ寺院では, マハーマンダパを介してナ ヴァランガにはいり，マハーマンダパが值交する軸線の交点になっ ている(図17)。

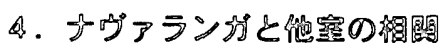

まずホイサラ寺院の本殿を構成する室の平面形についてナヴァラ ンガを中心に整理する。ナヴァランガ，ポルティコ，マハーマンダ パにみられる長方形, アンカナ付加平面は, ナヴァランガ中央の正 方形アンカナの周囲に付加的アンカナか酔置されたものと考えるこ とができる。アラシーケーレーのイーシュヴァラ寺院（E）のマハー マンダパの星形平面も九つのアンカナに相当する大きさの正方形を 回転させたものである。また，ガルバグリハ，シュカナースィはす ベて正方形平面であり，ホイサラ寺院の各室は正方形をもとに構成 されているのである。

次に各室の大きさを比較してみると，ナヴァランガは例外的に大 きいものを除き注24，中央の四本の柱で囲われたアンカナ6フィー 卜前後の正方形で, 全体はこのおおよそ三倍の正方形となる。ガル バグリハ, シュカナースイはナヴァランガの中央アンカナとほほ同 じ大きさで，ポルティコもほとんどがこれと同じ大きさとなる。正 方形以外の平面形がみられるナヴァランガ, マハーマンダパでは, 中央部の四本柱で囲われたアンカナとガルバグリ八の大きさはほほ 等しい（図5)。

これらの室，または室の中央にある正方形平面は全てガルバグリ 八に至る軸線上にあって (各寺院平面図の軸線参照)，この軸線は ナヴァランガ中央のアンカナで直交していることから，ホイサラ寺 院本殿の平面は，大きさの等しい正方形がナヴァランガの中央アン カナを中心とした軸線上に配置されて，それを基準として構成され ていると考えることができる。

一方，室の壁面構成をみると，ガルバグリハ，シュカナースイは すべて壁で囲われ，ポルティコ，マハーマンダパには壁がなくジャ ガティーで囲われている。ナヴァランガは壁で囲われることが多い が (167基)，一部をジャガティーで囲われたものがみられる（22 基）。後者では, ジャガティーでは半柱が, 壁面ではピラスターが 梁を受けている。この場合ピラスターは構造的に意味のあるもので, ジャガティーの半柱に相当する（図6）。前者では，ピラスターは, ガルバグリハ, シュカナースィでは四隅の他にニッチの両脇等に装 飾的に室内部を分節するものとして設けられることがあるが，ナヴァ 
ランガ, ポルティコ, マハーマンダパではすべてのピラスターが梁 を受ける位置に設けられている。

2-2) で述べたように，ジャガティーは壁面と互換性のあるも のと考えると，四辺を壁で囲われた一般的なナヴァランガの壁面の 構成を一部をジャガティーで囲われたものから考察することができ る。すなわち, ガルバグリハ, シュカナースィの壁の構造と, ポル ティコ, マハーマンダの柱, 梁の構造の双方がナヴァランガにみら れ，これら二つの構造がナヴァランガで混淆しているのである。こ れは, ニッチがガルバグリハを中心としてそのまわりの壁面に穿た れ，神格をまつるガルバグリハとニッチがひとまとまりでナヴァラ ンガの壁面に設けられ，入口側と対比されていることからも確かめ られる。

さらに，ガルバグリハとシュカナースィの間の壁厚はナヴァラン ガの外壁とほ等しいわに対し，シュカナースイ，またはシュカナー スイを介さないガルバグリハとナヴァランガの間の壁厚は外壁より 薄くなっている。寺院の主神をまつるガルバグリハは，本殿の最も 奥に配置されることで神聖化されるのはもとより，ガルバグリハの 壁厚によっても認識されるのである。この厚い壁と上部構造は，神 聖な山と洞窟か暗示されたもので注25，ニッチを含めた神格をまつ る壁面のまとまりがこの暗示による神聖な表現であるといえよう。

\section{5. 考察}

以上のナヴァランガを中心に考察したホイサラ寺院の平面の分析 をまとめると，まず，平面形の分析から，ホイサラ寺院本殿の平面 は正方形を基準とし，室または室の中央にある大きさのほほ等しい 正方形をナヴァランガ中央のアンカナで直交する軸線上に配置する ことによって構成されている点が指摘できる。構造に着目した壁面 構成の分析から，ガルバグリハ, シュカナースイか壁, ポルティコ, マハーマンダパが精梁の構造で，ナヴァランガで神格をまつる壁と 入口側の柱梁の構造力汶比されていることか汾る。これはジャガティー のあるナヴァランガで顕著であり，神格をまつるニッチも壁に設け られる。この二点をふまえて, 本殿の平面類型との相関と既報のデ ル・ボンタの分類との相関を考察する。

\section{5-1）. 平面類型とナヴァランガの平面形，壁面構成と の相関}

ナヴァランガの平面形が正方形または長方形で，一辺にアンカナ か配置されたものをみ.ると（表IIのA1，B1），三辺か壁に囲われ たものが $(\mathrm{A} 1 / \mathrm{b})$ 一軸型平面となり，コの字に壁に囲われたも のが (A 1 / c , B 1 / c ) 二軸型平面となる。コの字に壁に囲わ れるものは，入口を除いてガルバグリハか配置さ邡ており，コの字 に壁に囲われた正方形平面 $(\mathrm{A} 0 / \mathrm{c})$ もナヴァランガの左右壁に 設けられたニッチが大きく，二軸型平面に準じている。正方形平面 の二辺にアンカナか配置された平面形は $(\mathrm{A} 2 / \mathrm{c})$ 非対称となり, 正方形平面の三辺にア゙ンカナか配置された平面形は (A 3)，二軸 型平面であるか，この平面類型が並置されたもの（図18）である。 ここで，長辺でガルバグリハとつながる長方形平面のナヴァランガ を持つ（C̣）並置型平面を除いて考えると, 正方形平面のナヴァラ ンガの周りに配置されるアンカナと, ナヴァランガの壁面構成の差 異によってその他の平面類型を見ることができる。すなわち, 平面
類型の相違は，ナヴァランガの平面形と壁面構成の差異に基づいて いるのである。

ジャガティーに一部を囲われたナヴァランガを持つ寺院では，ガ ルバグリハ, シュカナースイ, ナヴァランガのガルバグリハ側の壁 がひとまとまりで，それらがナヴァランガ中央のアンカナの周囲に 配置されており，四辺を壁に囲われたナヴァランガを持つ寺院でも， 壁の一部がジャガティーに置き換わっていることを除いて，正方形 をもとにした平面構成，ニッチの配置に差異は認められない。四辺 を壁に囲われた寺院でも，ジャガティーを壁に置換えて考えること により，ジャガティーのある寺院と同様の構成であるといえよう。

平面類型の相違は, ナヴァランガの周りにあるガルバグリ八等, 他の室の配置ばかりではなく，ナヴァランガの平面形と，壁と柱梁 の構造が対比されるナヴァランガの壁面構成の差異に基ついており， ガルバグリハは信仰の対象である神像を納める場として壁厚等によっ て聖別されているが, 寺院平面の構成はナヴァランガを中心になさ れていると考えられるのである。

\section{5-2）.テル・ボンタの分類との比較}

最後に, 拙稿「ホイサラ朝寺院の平面についての類型学的考察」 で参照したデル・ボンタの分類との関連について簡単に触れる（表 I）。デル・ボンタの分類は，主にガルバグリハまわりの壁面の分 割に関するものなので，ここでは壁面構成との比較を行う。デル . ボンタは, ガルバグリ八のまわりの壁面が, 建築的モチーフと, 彫 像のレリーフの上下二層に分割されているものをハレービード・夕 イプ (17基)，細長いピラスターて装飾されているものをコーラヴァ ンガラ・タイプとし（20基），ハレービード・タイプをホイサラ独 自の表現であるとみている注26。

デル・ボンタのハレービード・タイプを本稿の方法にしたがって 分類すると, ナヴァランガの四辺が壁に囲われたものが 7 基 (33, 49, 93，97，114，122，128），三辺を壁で井われたものが2 基 (164，165），コの字に囲われたものが7 基 (166，167，168，169， 172 174，183），一辺を囲われたものが 1 基（175）となる。一方, コーラヴァンガラ・タイプは，四辺を壁に囲われたものが18基，そ の他三辺を壁に囲われたもの（187），コの字に壁に囲われたもの （162）が 1 基ずつである。全体的な特徴として，ハレービード . タイプには，ナヴァランガの一迟以上をジャガティーを用いて開放 しているものが半数以上を占めているのに対し（17基中10基），コー ラヴァンガラタイプには四辺を壁に囲われた閉鎖的なナヴァランガ が用いられている点が挙げられる（20基中18基）。

ガルバグリハのまわりの壁面分割を考慮に入れてハレービード . タイプのナヴァランガの壁面分割を見ると, ガルバグリハのまわり の二層に分割された壁面の下半分に浭続してナヴァランガの壁を， 上半分に漸続して格子空が設けられているものと理解することがで きる。つまり，ホイサラ独自の表現であるハレービード・タイプで は，ガルバグリハばかりではなくナヴァランガの壁面も二層となる 傾向がある点が指摘できるのである。

注 


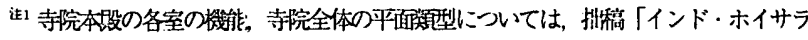

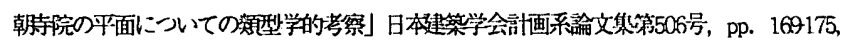

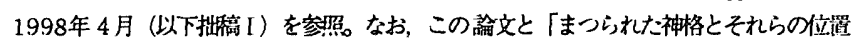

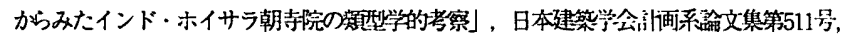
pp. 201-208，1998年9月（以下拙稿口）で用いた，「一軸奶称平面」「二軸 対称平面」の用語で表した平面形は，幦密に対称な平面形ではなく，混乱を 避けるために，本稿以降ではそれぞれ「一軸型」「二軸型」という用語に改 める。これにともない「非対称平面」「並置平面」も「非称型平面」「非 置型平面」に改める。

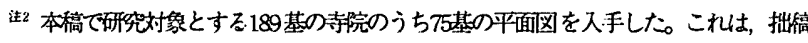

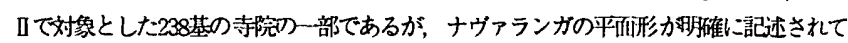
いるものを対象とした。またホイサラ朝の時代に建立され後の㭙代に增改筑がなされた寺 院は，建立当時のものを対奥とし增築部分は扱わない。

注3フォエケマの分類は, 郝完を記述するために便宜上なされたもので, 平面形を論じ るに胡分ではない。 Foekema, Gerard, Hoysala Architecture, Mediaeval Temples of Southern Karnataka Built During Hoysala Rule, New Delhi, 1994, pp.49-51.

注土正方形ナヴァランガ圠分割されることが一般的であるが，カルナータカ州南東部 のタミールナードゥとの州境にあるコーラール県には，ナヴァランガが咉の正方形と周 曲の四一の長方形の五つに分割されている寺院が4 基ある(表

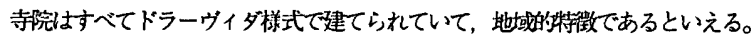

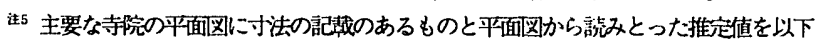
の表に示したこの推定值はMARに記载された平面図をイメージスキャナで読 这み，CADソフトを用いてインチ以下は切唅てたものである。表中の記号は 图5に対态してそれぞれ，X：ナヴァランガ中央の柱間のの内法寸法，X'， ナヴァランカの柱とビラスターの間の内法寸法，。：ナヴァランガ中央の柱

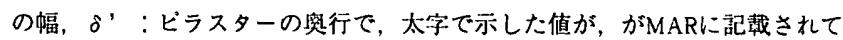
いるものであり，その他怦面図から読みとった推定值を示寸（単位はftと泀）。 「分割」閶の記号は图 5 に対応寸る。

\begin{tabular}{|c|c|c|c|c|c|c|c|c|}
\hline 08 & 国阽 & 分约 & $x$ & $x^{\prime}$ & 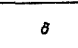 & $8^{\circ}$ & $x^{\prime}+8$ & $x^{\prime}+\theta+\theta^{\circ}$ \\
\hline 47 & 国1 & A & 6. 6" & 6.6. & $1.66^{\prime \prime}$ & 9" & $9^{\circ}$ & 8. 9" \\
\hline 164 & 国9 & B & 7. & $5^{\circ} 5^{\prime \prime}$ & $1^{\prime} 7^{\circ}$ & $10^{\prime \prime}$ & 7 & $7.10^{\circ}$ \\
\hline 168 & 国18 & B & $12^{\prime \prime} 4^{\circ}$ & $9^{\prime} 8^{\prime \prime}$ & $2^{\prime} 8^{\prime \prime}$ & $1.4 "$ & $12^{\prime} 4^{\prime \prime}$ & $13^{\prime} 8^{\prime \prime}$ \\
\hline 184 & 因2 & $B$ & 5. 2" & o" & 1. & 8" & $6^{\prime} 2^{\prime \prime}$ & $6^{\prime} 10^{\prime \prime}$ \\
\hline 187 & 囼8 & $B$ & 5.2" & $44^{\prime} \quad 11^{\prime \prime}$ & $1.3 "$ & 8" & $6^{\prime} 2^{\prime \prime}$ & 6. $10^{\prime \prime}$ \\
\hline 123 & 国17 & c & $5.8 "$ & $3^{\prime} 4^{\prime \prime}$ & 1.6 " & "و & $4^{\prime} 10^{\circ}$ & $5^{\prime} 7^{\prime \prime}$ \\
\hline
\end{tabular}

iะ6 本䅭では，最も数が多く他の平面形の基染となる九分割の正方形ナヴア ランガと，正方形の辺の中块部にアンカナを配置して中央部が笑出したナヴ ランガの平面形を比べて，単純な平面形から褀雑なもの人と展開したものと 考え「アンカナ付加平面」と表現する。これは経時的な变化をともなう表現 ではなく，平面形の複雑さを考密したものである。

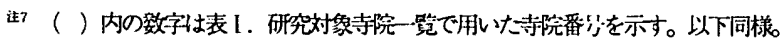

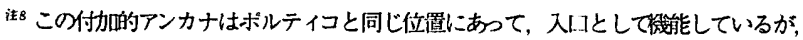
ガァランガと一体の室として証識できるものを考え，ポルティコとは正方形平面のナヴ ランガとの間の壁の有無によって区別して考える。

注9 ゴーヴインダナハッリのバンチャリンゲーシュヴァラ郝院は (187/図9)，最も

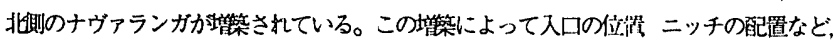
ブランの対称性カ泆われている。

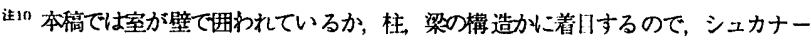
スィス口のように周りか壁で囲われたものは壁面に穿たれは開吅部であると考え，周りが ジャガティー (後述) であるポルティコからナヴァランガへの入イとは区別して考える。

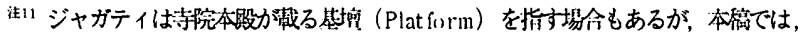

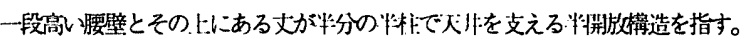

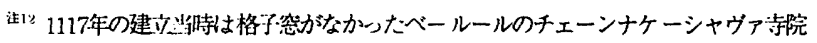
は，1173年の增智标格子空力取付けだれている。(MAR 1931 pp. 26-28.)

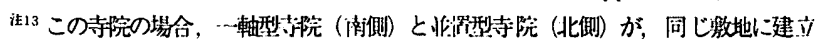

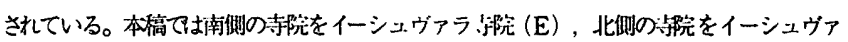
ラ寺院 (D) として区別する。MAR 1930 pp.61-67, pi. XIV.

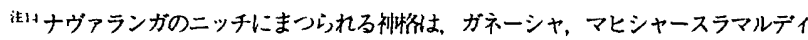
が多く、ニッチの数か增えるにしたがって，スーリヤ，サラスヴアティ，サブタマトリカ

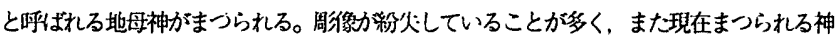

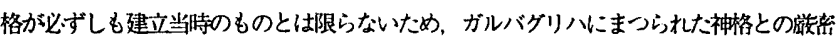

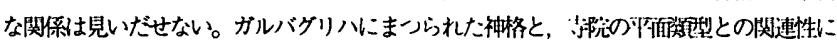

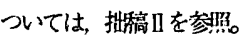

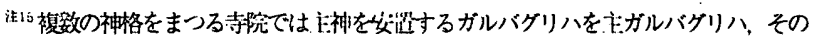
他の神格を安置するガルバダリ八を従ガルバグリハと呼儿でメ則する。

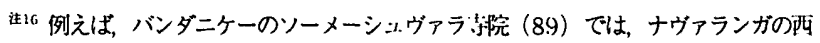

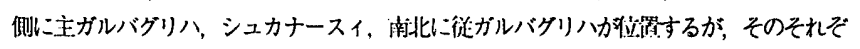

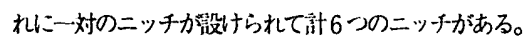

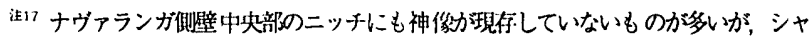

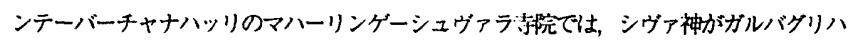
に, ウイシュヌ神とブラフマー神がニッチにますの゙れる（MAR 1939 p. 42.)。これLた，

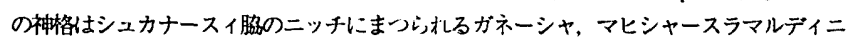
神とは異なり，ガルバタリハにまつられることが多いヒンドリー教の三大神である。

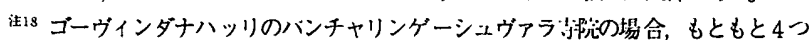
のガルバグリハからなる寺院の北側㙞筑されたものである。大きめの二ッチはもとの寺

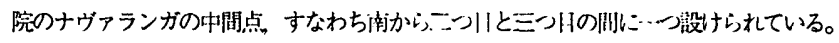

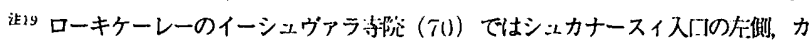
ンナガラのカッレーシュヴアラ寺院（146）のでは倠に設けヴれている。

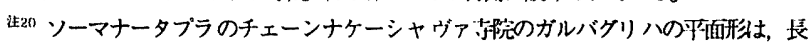

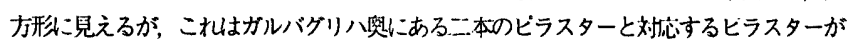
前面にないなめで, 天井は正方形である。ゴーヴインダナハッリのバンチャリンゲーシュ ヴァラ寺院で墺衍7'6"幅6'6”であるが（MAR1933p.15），それぞれ梁型とビラ スターによって区分されたひとののアンカナで，アンカナが衫数まとまって知形を是して

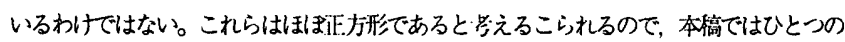
アンカナからなる正施のガルバグリハ, シッカナースイに令めて考える。

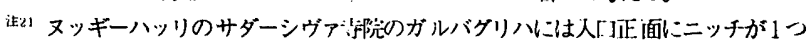
あるが、ビラスターは四晚にしかない（MAR 1917 pp.11-12,pl.6）。

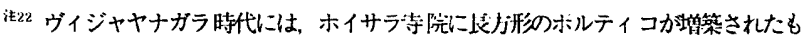

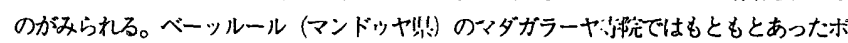

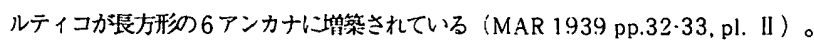

注23 長方形平面のマハーマンダハはざールールのチェーンナケーシャヴア寺院にみた れるが (Narasimhachar, R, The Kesava Temple at Bulur, 1911, rpt 1982, New

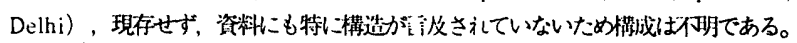

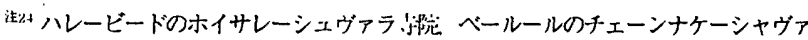
寺院は, ホイサラ郝完のうちでは例必们に规悦が人きい。

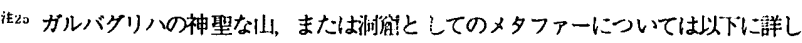
い. Stella Kramrisch, The Hindu T(mole, pp. 161 165.

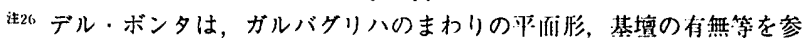

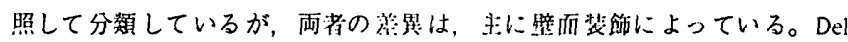
Bonta, Robeart John, The Hoysala Style: Architectural Development and Artists, 12 th and 13 th Centuries, A. D.. 1978. University of Michigan.

(1999年 7 月 10 日原稿受理，2000年 1 月 28 日採用決定） 